\section{MICHAEL KENNEDY}

\section{The}

\section{Hallé Tradition}

'The history of the Halle Orchestra is in essence the history of English music during the past hundred years . . . an absorbing book.'-Times Educational Supplement.

'The author's intense love of music comes through every part of the book. In the space of 400 pages he tells a fascinating tale.'Cheshire Life.

' $H$ is achievement is a sympathy and understanding beyond his years. - Neville Cardus in The Listener.

'Mr. Kennedy writes gracefully and well; he gives a thoroughly balanced, rounded and engrossing picture of the Halle in its first hundred years ... a necessary and important as well as welcome book.'-Yorkshire Post. 45 illustrations 35 s, net

MANCHESTER UNIVERSITY PRESS
LOWE \& BRYDONE

(PRINTERS) LIMITED

VICTORIA ROAD, LONDON, N.W.10

TELEPHONE - ELGAR 7821 - (4 lines)

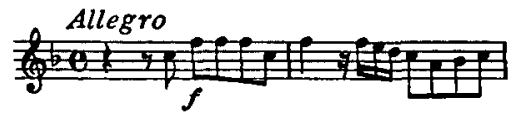

The largest

MUSIC ENGRAVERS and

MUSIC PRINTERS

in the

Commonwealth

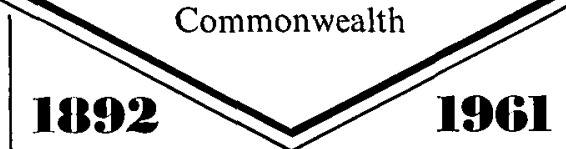

MUSIC OF EVERY KIND

ENGRAVED

and

PRINTED

\title{
POCKET SCORES
}

of works by

\section{FREDERICK DELIUS}

edited by

Sir Thomas Beecham, Bart.

HPS 41

APPALACHIA

17s 6d

HPS 23

\section{THREE ORCHESTRAL PIECES}

Intermezzo from 'Hassan'

Serenade from 'Hassan'

The Walk to the Paradise Garden

6s Od
HPS 43

SEA DRIFT

12s 6d

HPS 86

THREE ORCHESTRAL PIECES

La Calinda

Intermezzo from 'Fennimore and Gerda' 'Irmelin' Prelude

6s 6d 


\section{Ralph Vaughan Williams}

\section{SONGS OF TRAVEL}

\section{COMPLETE EDITION}

for low voice and piano

Words by Robert Louis Stevenson

1. The Vagabond

2. Let Beauty Awake

3. The Roadside Fire

4. Youth and Love

5. In Dreams

6. The Infinite Shining Heavens

7. Whither must I wander?

8. Bright is the Ring of Words

9. I have Trod the Upward and the Downward Slope

Price ios

\section{ON WENLOCK EDGE}

\section{A CYCLE OF SIX SONGS FOR TENOR VOICE}

with an accompaniment of piano and optional string quartet Words by A. E. Housman

1. On Wenlock Edge

2. From Far, from Eve and Morning

3. Is my Team Ploughing?

4. Oh, when I was in Love with You

5. Bredon Hill

6. Clun

PRICE 155

\section{Boosey \& Hawkes}

295 Regent Street, London W I 